\title{
Deficit Irrigation Effects on Soil Chemistry Properties Yield and, Yield Components and Fruit Firmness of Cucumber and (Cucumis sativus L.) under Arid Condition of Al-Hassa, Saudi Arabia
}

\author{
M. M. El-Garawany and N. S. Albaloushi * \\ Agricultural and Veterinary Training and Research Station, and *Department of Agriculture \\ Systems Engineering, College of Agricultural and Food Sciences, King Faisal University, Al-Hassa, \\ Saudi Arabia
}

\begin{abstract}
A field experiment was carried out in the greenhouse at the Agricultural and Veterinary Training and Research Station, King Faisal University, Al-Hassa, Saudi Arabia in season of 2011/2012, to investigate the effects of six water irrigation deficit treatments on physical, mechanical properties, yield and yield components of cucumber (Cucumis sativus L.). Complete Block Design using three replicates. The deficit irrigation treatments were T1 (100\% ETc), T2 (70\% ETc), T3 (70\% ETc after full germination until end of season for every stages), T4 (70\% ETc at vegetative stage until season end), T5 (70\% ETc at flowering stage until season end), and T6 (70\% ETc at first harvest until season end). The results revealed that the deficit irrigation has significant effect on yield and yield component and has no significant effect on fruit firmness. The highest values of plant length $(\mathrm{cm})$, no of fruits /plant, total fruit weigh $(\mathrm{kg}) /$ plant, marketable fruits weight $(\mathrm{kg}) / \mathrm{plant}$ and ratio of marketable fruit yield/ fruit yield were found when plants treated with $\mathrm{T} 1$ and $\mathrm{T} 2$ with no significant differences between them. The treatments appeared significant effect on the physical characteristics (length, width, thickness, arithmetic mean diameter, Geometric mean diameter, aspect ratio, cylinderity. The highest mean values of physical properties were found with plants exposed to T1 and T2. The highest water use efficiency was found in treated plant with T2. Surface soil treated with T1, T3, T4, T5, and T6 has lower acidity (pH), electrical conductivity (EC), sodium adsorption ratio (SAR) and lower contents of total $\mathrm{N}$, and availability of nutrients $\mathrm{K}, \mathrm{P}, \mathrm{Fe}, \mathrm{Mn}, \mathrm{Zn}$ and $\mathrm{Cu}$ than the treated soil with T2 .
\end{abstract}

Keywords: deficit irrigation, Cucumis sativus, yield component, physical properties and firmness.

\section{Introduction}

Saudi Arabia lies in arid zone and suffers from shortage in water resource. The about $85 \%$ of the total amount water in the world are consumed for irrigation of agricultural crops (Van Schilfgaarde, 1994). In many localities, water is the limiting factor for agricultural crops and also increasing yield. Therefore for judicial use of water, attempts should be made to obtain maximum yield with minimum water supply (Nahar and Ralph, 2002). Plant water status controls the physiological processes and conditions which determine the quality and quantity of growth (Kramer, 1969). Efficient use of water by irrigation is becoming increasingly important, and alternative water application method such as drip, may contribute substantially to the best use of water for agriculture and improving irrigation efficiency.

In areas of recurrent water scarcity and long drought spells, deficit irrigation (DI) is a common practice, traditional recommended, mitigating yield reductions (Kirda, 2000). DI 
involves irrigating the entire root zone with less than full evapotranspiration (ETc) throughout the season. It can lead to increased net income where water supplies are limited (English and Raja, 1996). Worldwide, successful attempts have been documented regarding the use of deficit irrigation method to improve irrigation water use efficiency (IWUE) in various crop species (Arzani et al., 2000; Hutton, 2000; Grant et al., 2004; Kirda et al., 2004; Cifre et al., 2005; Wakrim et al., 2005). The decline in water availability for irrigation and the positive results obtained in some fruit tree crops have renewed the interest in developing information on deficit irrigation for a variety of crops (FAO, 2002, Fereres and Evans, 2006).

Cucumber (Cucumis sativus L.) is one of the popular vegetables in many countries. It belongs to the family of cucurbitaceae which has 118 genera and 825 species (FAO, 2002). The fruit of this plant is green in color and depending on the variety; it can be small or large. The external and internal properties play a good role in determination the quality of vegetables fruits (Albaloushi, 2012).

Chartzoulakis and Drosos (1997) indicated that the cucumber is more greenhouse crops consuming water, where the daily water consumption reach to 1.1 times the amount of evaporation from the Class A pan evaporation (Epan). Newly appeared, the so called deficit irrigation where the deficit (or regulated deficit) irrigation is one way of maximizing water use efficiency (WUE) for higher yields per unit of irrigation water applied: the crop is exposed to a certain level of water stress either during a particular period or throughout the whole growing season Kirda (2000). Many of agricultural practices, especially method and quantities of irrigation water, play an important role in determination the quality and quantity of the crop yields .
Physical properties of food materials also effect on handling, conveying characteristics and estimating the cooling and heating loads Mohsenin (1986). Physical attributes such as size, shape, bulk density and porosity are major consideration in designing of hopper, drying and aeration systems as these properties effect on the resistance to airflow of stored mass and many reports about qualitative evaluation of agricultural products was published (Russell, 1973; Amer et al., 2011). Data on physical properties of agro food materials are valuable because they are needed as input to models predicting the quality and behavior of products in preharvest, harvest, and post-harvest (Nesvadba et al., 2007).

To design and optimization a machine for handling, cleaning, conveying, and storing, the physical attributes, their relationships and texture (firmness) properties must be known (Mirzaei et al., 2008). Among these physical characterizes length, width, thickness, mass, volume, projected areas and center of gravity are the most important factors in sizing systems (Mohsenin, 1986). Yehia et al. (2009) studied the physical properties and characteristics of some agricultural crops and fruits, which can be used in the design and development of equipment. Bitter cucumbers result from poor growing conditions low soil fertility, high temperatures, and drought (http://msucares.com/

lawn/garden/vegetables/list/cucumber.html., 2014).

As irrigation water is considered one of the important agriculture practices to determined yield and yield component and physical properties of fruits. Therefore, the goal of this study was evaluate the effect of deficit irrigation water on yield and yield component, some physical properties of cucumber fruits and changes in some 
chemical properties of soil under Al-Hassa region, Saudi Arabia.

\section{Materials and Methods}

Field experiment was carried out at the Agricultural and veterinary Training and Research station, King Faisal University, AlHassa, Saudi Arabia in season of 2011/2012. The soil of the experimental site was sandy clay loam, having $\mathrm{pH}$ (7.5), EC (1.3 dSm-1), O.M (0.05 \%), total N (0.016\%), and available P (3.75 ppm) and $\mathrm{K}$ (105 ppm). Random complete block design with three replicates was used to conduct in the green house. Six deficit irrigation treatments were investigated in the current study. The first treatment (T1) was $100 \%$ ETc of the water requirements, the second one (T2) irrigation at all periods of the crop by $70 \%$ ETc of the water requirements and the other four treatments were at deficit at four stages of growth (T3: from complete germination until the fifth true leaves, T4: vegetative, T5: from flowering until the fifth harvest and T6: from the six harvest until end of season) as presented in Table 1. The seedling rate was $2.4 \mathrm{~kg} \mathrm{ha}^{-1}$. Fertilizers were supplied for the cropping period in the same amounts; before transplanting of cucumber seedlings, soil was mixed with 8.5 ton/ha of organic manure. Nutrient supply followed local practices consisting of giving $\mathrm{N}$ in the form of ammonium nitrate $\left(\mathrm{NH}_{4} \mathrm{NO}_{3}\right), \quad \mathrm{P}_{2} \mathrm{O}_{5}$ as superphosphate and $\mathrm{K}_{2} \mathrm{O}$ as potassium sulfate at rates of 200, 150 and $150 \mathrm{~kg} \mathrm{ha}^{-1}$, respectively.

The $\mathrm{P}_{2} \mathrm{O}_{5}$ and $\mathrm{K}_{2} \mathrm{O}$ fertilizers were applied as basal dose before transplanting. The fertilizers were applied on the soil. Nitrogen was divided to two doses, first dose was before seedling transplanting and the second dose was after 20 days from the first dose. Plants of cucumber (cv. Arigon), a variety widely used in the region, were gently transplanted in 5 and 8 December in the 2011 growing season. The distance between rows was $75 \mathrm{~cm}$ and between each two plants in same row was $50 \mathrm{~cm}$. Each elementary plot consisted of five rows. Individual plot size was $48 \mathrm{~m}^{2}(12 \mathrm{~m} \mathrm{x} 4 \mathrm{~m})$. All plots were drip irrigated with water from a well having an $\mathrm{EC}_{\mathrm{i}}$ of $1.6 \mathrm{dS} \mathrm{m}^{-1}$.

Table 1. Used deficit irrigation (DI) treatments and quantity of irrigation water in the study.

\begin{tabular}{cc}
\hline Treatment & Stage of applied treatment \\
T1 & $100 \% \mathrm{ET}_{\mathrm{c}}$ at all growth stages \\
$\mathrm{T} 2$ & $70 \% \mathrm{ET}_{\mathrm{c}}$ at all growth stages \\
$\mathrm{T} 3$ & $70 \% \mathrm{ETc}$ after full germination until end \\
of season
\end{tabular}

The drip irrigation system consists of main line 4" PVC line and the sub main line 3" PVC line, the emitter GR type $4 \mathrm{~L} \mathrm{~h}^{-1}$ and spacing of $0.5 \mathrm{~m}$ apart between drippers. Each dripper had a $4 \mathrm{~L} / \mathrm{h}$ flow rate. Water for each block passed through a water meter, gate valve, before passing through laterals placed in every cucumber row. A control mini-valve in the lateral permits use or non-use of the dripper line. The amount of applied irrigation water was measured by flow meter and was calculated according Vermeiren and Gopling (1984) equation

$$
A I W=\frac{E T p X K c X K r X \text { Interval }}{E a}+L R
$$

Where: AIW = applied irrigation water depth $(\mathrm{mm} /$ day $), \quad$ ETp $=$ Potential evapotranspiration ( $\mathrm{mm} /$ day) values obtained by class A pan method (FAO, 1979) and calculated as follows: 


$$
\text { ETP }=\text { Epan } X \text { Kpan }
$$

Where $\mathrm{E}_{\mathrm{pan}}=$ measured pan evaporation daily values $(\mathrm{mm} /$ day $), \mathrm{K}_{\mathrm{pan}}=$ Pan coefficient for class $\mathrm{A}$ pan values depend on the relative humidity, wind speed and the site conditions (bare or cultivated). A $\mathrm{k}_{\text {pan }}$ value of 0.75 was used for the experimental site.

$\mathrm{K}_{\mathrm{c}}=$ crop coefficient for cucumber (FAO, 1979). $K_{r}=$ reduction factor that depends on ground cover. A $\mathrm{K}_{\mathrm{r}}$ value of 0.6 was used since lateral spacing is 2 meters apart (FAO, 1979).

$$
\mathrm{E}_{\mathrm{a}}=\text { Irrigation efficiency }=\mathrm{K} 1 \times \mathrm{K} 2=0.85
$$

Where: $\mathrm{K} 1=$ Emitter uniformity coefficient $=0.90$ for the drip system at the site, $\mathrm{K} 2=$ Drip irrigation system efficiency $=0.94$ for the drip system at the site. Irrigation intervals $=1$ day for the experimental site. LR = Leaching requirements (No additional water for leaching was added during the growing seasons due to the low EC values of irrigation water and soil profile).

Water utilization efficiency (WUtE) values were calculated from the following equation (Jensen, 1983) as follows:

$W U t E=\frac{\text { Total fresh fruits of cucumber }(\mathrm{Ton} / \mathrm{ha} .)}{\text { applied irrigation water }\left(\mathrm{m}^{3} / \mathrm{ha}\right) .}$

\section{The Physical Properties}

Five plants per line were selected and fruits in good quality from every plant were chosen. The fruits were packed in paper pages then, directly sent to the research laboratory, Agricultural and veterinary Training and Research station, King Faisal University, AlHassa, Saudi Arabia for determination of physical and firmness properties. All measurements were carried out at room temperature. The fruit physical properties were obtained from 20 fruits in good quality (intermediate cylindrical shape) which were selected according to fruit shape rating. The rating reflected how straight, uniform and cylindrical where the fruit shape were based on a scale of 1 to $9,(1$ to $3=$ poor, 4 to $6=$ intermediate, and 7 to $9=$ excellent) (Strefeler and Wehner, 1986). The linear dimensions, i.e. length (L), width (W) and thickness (T) were measured using digital micrometer (GUANGLU, Germany) with an accuracy of $0.01 \mathrm{~mm}$. The largest dimension was chosen as length and the smallest one as diameter. The arithmetic mean diameter (Da) and the geometric mean diameter (Dg) were then calculated according to Mohsenin (1986); the aspect ratio ( $\mathrm{Ra}$ ) in percent is used in classification of cucumber shape as recommended by (Razavi and Parvar, 2007). Determination of sphericity or cylinderity was calculated according to Mohsenin, (1970). Surface area was defined as the total area over the outside of the cucumber fruits. Surface area (S) was theoretically calculated as apparent surface area by Mohsenin (1986):

$$
S=\pi D g^{2}
$$

\section{Soil Chemical Analysis}

A composite sample of $30 \mathrm{~cm}$ deep soil was used for chemical analysis before preparing the soil for planting and after harvest. The samples were air dried, ground, and sieved through $2 \mathrm{~mm}$ for analysis in soil. The $\mathrm{pH}, \mathrm{EC}$ $\mathrm{dS} \mathrm{m}^{-1}$, and sodium adsorption ratio (SAR), total calcium carbonate $\%$, organic matter content, total nitrogen $\%$, and available nutrients $(\mathrm{K}, \mathrm{P}, \mathrm{Mn}, \mathrm{Fe}, \mathrm{Zn}$, and $\mathrm{Cu}$ ) were estimated according to Page et al., (1982).

The obtained data were statistically analyzed using SAS software package (SAS, 2001), and the least significant difference (LSD) tests were used to compare the differences among treatments means as illustrated by Steel and Torries (1980).

\section{Results and Discussion}


Analysis of variance of The Growth characteristics, yield and yield components

Analysis of variance of the cucumber growth characteristics under the effects of six irrigation water levels are presented in Table (2).

Table 2. Mean of square for plant length, no. of fruits/plant, total fruits weight/plant, marketable fruits weight /plant, ratio of marketable fruit weight/ total fruits weight and fruits firmness of cucumber as affected by different irrigation treatments factors.

\begin{tabular}{|c|c|c|c|c|c|c|c|}
\hline \multirow{2}{*}{$\begin{array}{c}\text { Source } \\
\text { of } \\
\text { variation }\end{array}$} & \multirow{2}{*}{$\begin{array}{c}\text { Degree } \\
\text { of } \\
\text { freedo } \\
m\end{array}$} & \multicolumn{5}{|c|}{$\begin{array}{c}\text { Means Squares } \\
\text { Growth and Yield characteristics }\end{array}$} & \multirow[b]{2}{*}{$\begin{array}{c}\text { Fruit } \\
\text { firmne } \\
\text { ss } \\
(\mathrm{kg})\end{array}$} \\
\hline & & $\begin{array}{c}\text { Plant } \\
\text { lengt } \\
\mathrm{h} \\
(\mathrm{cm})\end{array}$ & $\begin{array}{c}\text { No. } \\
\text { of } \\
\text { fruits } \\
\text { /plant }\end{array}$ & $\begin{array}{c}\text { Total } \\
\text { fruits } \\
\text { Weight } \\
(\mathrm{Kg}) / \\
\text { plant }\end{array}$ & $\begin{array}{c}\text { Marketa } \\
\text { ble fruits } \\
\text { Weight } \\
(\mathrm{kg}) \\
\text { /plant }\end{array}$ & $\begin{array}{l}\text { Ratio of } \\
\text { fruits } \\
\text { marketabl } \\
\text { e yield/ } \\
\text { total fruit } \\
\text { yield }\end{array}$ & \\
\hline Rep. & 2 & 10.72 & 20.76 & 0.269 & 0.007 & 0.0004 & 0.284 \\
\hline $\mathrm{T}$ & 5 & 30.76 & $67.7^{*}$ & $1.011^{* *}$ & $0.175^{* *}$ & $0.0070^{*}$ & $0.15^{\mathrm{NS}}$ \\
\hline Error & 10 & 6.12 & 7.23 & 0.134 & 0.0036 & 0.0018 & 0.146 \\
\hline
\end{tabular}

*, **: significant at $\mathrm{p}<0.05$ and $\mathrm{p}<0.01$ levels of probability respectively

Ns: not significant at $\mathrm{p}<0.05$ level.

Notice: the area of one plant was $75 \mathrm{~cm} * 50 \mathrm{~cm}$ A (Rep.= replications and $\mathrm{T}=$ treatments).

The results revealed significant differences due to applied deficit irrigation with regard plant length $(\mathrm{p}<0.05)$, no. of fruits/plant $(\mathrm{p}<$ $0.01)$, weight of fruits/plant $(\mathrm{p}<0.01)$ weight of marketable fruits/plant and fruit marketable yield/ total fruit yield Ratio, while the differences were not significant concerning fruit firmness parameters. These findings are consistent with the results found by Alomran, et al., (2013) on their study on response of cucumber to deficit irrigation in Saudi Arabia where they showed that the yield and quality of the fruit were significantly affected by deficit irrigation treatments.

Effect of deficit irrigation treatments on Plant length (cm), no .of fruits /plant, total fruits weight (kg)/plant marketable fruits weight (kg)/plant, ratio of fruit marketable yield/total fruit yield and fruit firmness of cucumber:

The results of the effects of deficit irrigation treatments on plant length $(\mathrm{cm})$, no. of fruits /plant, total fruits weight $(\mathrm{kg}) /$ plant, marketable fruit weight $(\mathrm{kg}) / \mathrm{plant}$, ratio of fruits marketable yield/ total fruit yield and fruit firmness of cucumber are presented in Table (3). The results revealed significant differences between applied deficit irrigation treatments (T1, T2, T3, T4, T5, and T6) with regard plant length $(\mathrm{cm})$, no. of fruit /plant, weight of fruit /plant (g),weight of marketable fruit /plant $(\mathrm{kg})$ and fruit firmness. These results are in agreement with that obtained by Amer, et al., (2011) in their study on the effect of deficit irrigation and fertilizer on cucumber where they found that the morphological properties decreased with increasing the deficit irrigation from $100 \% \mathrm{ETc}$ to $64 \% \mathrm{ETc}$. Concerning length of cucumber plants, the highest value $(72.67 \mathrm{~cm})$ was obtained at deficit irrigation $\mathrm{T} 1$, while the shortest plants $(65.33 \mathrm{~cm})$ were obtained under deficit irrigation T3 and T4 (Table 5). The deficit irrigation $\mathrm{T} 1$ produced the highest fruit weight/plant $(46.00 \mathrm{~g})$, whereas the deficit irrigation T6 produced the least weight of fruits/plant (33.77g). Higher weight of fruit/plant was recorded by deficit irrigation T1 (4.81 kg) followed by T2 $(4.69 \mathrm{~kg})$. The least weight of fruits/plant was produced by the deficit irrigation T3 (3.44 kg) (Table 3). There were no significant differences between the deficit irrigation $\mathrm{T} 1$ and $\mathrm{T} 2$. The cucumber plants grown under $100 \%$ ETc (T1) produced the highest marketable fruits/plant $(1.28 \mathrm{~kg})$ followed by T2 with $1.11 \mathrm{~kg}$. These results are in agreement with that obtained by El-Waraky, (1988), and Amer, et al., (2011). They mentioned that the yield of cucumber is negatively affected with deficit irrigation from $100 \%$ ETc to $64 \%$ ETc. The plants supplied 
with T1 treatment improved the ratio of marketable fruit/plant and weight of fruit/plant than those received other treatments. The highest ratio of marketable fruit/plant and weight of fruits/plant (0.28) was obtained at T1 (100\% ETc), while the least ratio was 0.15 and obtained by the deficit irrigation T5 (70\% ETc except fruit stage). These results are in agreement with finding of Amer, et al., (2011) and Xuesen, et al., (2003) in their study on the cucumber plant where they mentioned that the fruit yields of cucumber were highly influenced by the total volume of irrigation water at every growth stage. Regarding fruit firmness the data of Table (3) revealed that the fruit firmness was not significantly affected by the applied deficit irrigation treatments. However, higher firmness values were obtained under the deficit irrigation treatments T4 (2.20) and T5 (2.80). From above results, the deficit irrigation impact on cucumber crop and its components. Where, the applied deficit irrigation at different periods of growth led to a decline in the qualities and quantity of cucumber fruits comparing to irrigation at $100 \%$ and $70 \%$ of ETc. While the regularity of irrigation amount during the crop growth has led to higher values for the previous characteristics. Therefore optimum growth and good quality of fruits can only be achieved if water is properly managed and enough for metabolism of plant where growth is dramatically affected by timing and amount of applied water during production of plant growth which are more sensitive to water stress.

Table 3. Effect of deficit irrigation treatments (T1-T6) on plant length (PL, cm), no. of fruits/plant (NF/P), total fruits weight /plant (TFW/P, Kg), marketable fruits weight $(\mathrm{kg}) /$ plant $(\mathrm{MFW} / \mathrm{P})$, ratio of fruit marketable yield/ total fruits yield (MFW/TFW) and Firmness (Fr) of cucumber

\begin{tabular}{|c|c|c|c|c|c|c|}
\hline$\underset{\text { nt }^{*}}{\text { Treatme }}$ & $\begin{array}{c}\text { PL } \\
(\mathrm{cm})\end{array}$ & $\begin{array}{c}\mathbf{N F} / \\
\mathbf{P}\end{array}$ & $\begin{array}{c}\text { TFW } \\
\text { /P } \\
(\mathrm{Kg})\end{array}$ & $\begin{array}{c}\text { MFW } \\
/ \mathbf{P} \\
(\mathbf{K g}) \\
\end{array}$ & $\begin{array}{c}\mathrm{MFW} / \mathrm{T} \\
\mathrm{FW}\end{array}$ & Fr \\
\hline $\mathrm{T} 1$ & $\begin{array}{c}72.67 \\
\mathrm{a}\end{array}$ & $\begin{array}{c}46.0 \\
0 \mathrm{a}\end{array}$ & $4.81 \mathrm{a}$ & $1.28 \mathrm{a}$ & $0.28 \mathrm{a}$ & $\begin{array}{c}2.63 \\
3 a\end{array}$ \\
\hline $\mathrm{T} 2$ & $\begin{array}{l}72.00 \\
\mathrm{ab}\end{array}$ & $\begin{array}{c}44.3 \\
3 \mathrm{a}\end{array}$ & $4.69 \mathrm{a}$ & $1.11 \mathrm{~b}$ & $0.25 \mathrm{ab}$ & $\begin{array}{c}2.30 \\
0 \mathrm{a}\end{array}$ \\
\hline T3 & $\begin{array}{c}65.33 \\
\mathrm{c}\end{array}$ & $\begin{array}{c}37.9 \\
7 \mathrm{~b}\end{array}$ & $3.88 \mathrm{~b}$ & $0.88 \mathrm{c}$ & $0.19 b c$ & $\begin{array}{c}2.60 \\
0 \mathrm{a}\end{array}$ \\
\hline $\mathrm{T} 4$ & $\begin{array}{c}65.33 \\
\mathrm{c}\end{array}$ & $\begin{array}{c}37.2 \\
3 b\end{array}$ & $3.79 b$ & $0.71 \mathrm{~d}$ & $0.18 b c$ & $\begin{array}{c}2.20 \\
0 \mathrm{a}\end{array}$ \\
\hline T5 & $\begin{array}{c}67.33 \\
c\end{array}$ & $\begin{array}{c}36.8 \\
7 \mathrm{~b}\end{array}$ & $3.57 \mathrm{~b}$ & $\begin{array}{c}0.68 \\
d\end{array}$ & $0.15 \mathrm{c}$ & $\begin{array}{c}2.80 \\
0 \mathrm{a}\end{array}$ \\
\hline T6 & $\begin{array}{c}68.00 \\
\text { bc }\end{array}$ & $\begin{array}{c}33.7 \\
7 \mathrm{~b}\end{array}$ & $3.44 \mathrm{~b}$ & $1.10 \mathrm{~b}$ & $0.23 \mathrm{ab}$ & $\begin{array}{c}2.40 \\
0 \mathrm{a} \\
\end{array}$ \\
\hline $\mathrm{LSD}_{0.05}$ & 4.50 & 4.89 & 0.67 & 0.109 & 0.077 & $\begin{array}{c}0.69 \\
5\end{array}$ \\
\hline
\end{tabular}

*Any two means not sharing the same letter in common in a column differ significantly at $5 \%$ probability

${ }^{* *} \mathrm{~T} 1\left(100 \% \mathrm{ET}_{\mathrm{c}}\right.$ at all growth stages $), \mathrm{T} 2\left(70 \% \mathrm{ET}_{\mathrm{c}}\right.$ at all growth stages), $\mathrm{T} 3\left(70 \% \mathrm{ET}_{\mathrm{c}}\right.$ after full germination until end of season), $\mathrm{T} 4$ $\left(70 \% \mathrm{ET}_{\mathrm{c}}\right.$ at vegetative stage until season end, $\mathrm{T} 5\left(70 \% \mathrm{ET}_{\mathrm{c}}\right.$, at flowering stage until season end), and $\mathrm{T} 6\left(70 \% \mathrm{ET}_{\mathrm{c}}\right.$ at first harvest until season end).

\section{Effect of deficit irrigation on physical properties of fruits}

Variance analyses of fruit physical properties of the cucumber under the effects of six irrigation water levels are presented in Table (4). Results showed that the nonsignificant effects were found in the of irrigation treatments to length, width, thickness, arithmetic mean diameter, geometric mean diameter and cylindered of cucumber fruits, whereas aspect ratio influenced significantly by deficit irrigation treatments $(\mathrm{p}<0.05)$.

The effect of deficit irrigation treatments on physical characteristics such as length, width, thickness, arithmetic mean diameter, geometric mean diameter, aspect ratio of cucumber fruits were presented in Fig. (1). The results revealed, no significant differences between the physical characteristics under the applied deficit irrigation treatments. However, 
higher fruit length $(143.3 \mathrm{~mm})$ was obtained under deficit irrigation treatment T6 as compared to other tested treatments.

Table 4. Mean of square of fruits physical characteristics (length, width, thickness, arithmetic mean diameter, geometric mean diameter, aspect ratio and cylinderity) of cucumber under the different deficit irrigation treatments.

\begin{tabular}{|c|c|c|c|c|c|c|c|c|}
\hline \multirow{2}{*}{$\begin{array}{c}\text { Source } \\
\text { of } \\
\text { variati } \\
\text { ons }\end{array}$} & \multirow{2}{*}{$\begin{array}{c}\text { Degr } \\
\text { ee } \\
\text { of } \\
\text { freed } \\
\text { om }\end{array}$} & \multicolumn{7}{|c|}{$\begin{array}{c}\text { Means Squares } \\
\text { fruits physical characteristics }\end{array}$} \\
\hline & & $\begin{array}{c}\mathrm{L} \\
(\mathbf{m m})\end{array}$ & $\begin{array}{l}\text { W } \\
(\mathbf{m} \\
\mathbf{m})\end{array}$ & $\begin{array}{l}\text { Tn } \\
(\mathbf{m} \\
\mathbf{m})\end{array}$ & Da & Dg & $\mathbf{R a}$ & $\emptyset$ \\
\hline Rep. & 2 & 26.49 & 7.77 & 9.34 & $\begin{array}{c}78.4 \\
6\end{array}$ & 9.17 & $\begin{array}{c}5.5 \\
1\end{array}$ & $\begin{array}{c}0.000 \\
5\end{array}$ \\
\hline $\mathrm{T}$ & 5 & $\underset{\text { NS }}{27.33}$ & $\begin{array}{c}1.83 \\
\text { NS }\end{array}$ & $\begin{array}{c}3.20 \\
\mathrm{NS}\end{array}$ & $\begin{array}{c}31.8 \\
1^{\mathrm{NS}}\end{array}$ & $\begin{array}{c}3.65 \\
\text { NS }\end{array}$ & $\begin{array}{c}1.1 \\
7^{*}\end{array}$ & $\begin{array}{c}0.000 \\
1^{\mathrm{NS}}\end{array}$ \\
\hline Error & 10 & 24.38 & 5.67 & 2.31 & $\begin{array}{c}38.2 \\
0 \\
\end{array}$ & 5.12 & $\begin{array}{c}0.6 \\
7 \\
\end{array}$ & $\begin{array}{c}0.000 \\
12 \\
\end{array}$ \\
\hline
\end{tabular}

Ns: not significant at $\mathrm{p}<0.05$ and

*: significant at $\mathrm{p}<0.05$ level of probability respectively

(Rep. $=$ Replications, $\mathrm{T}=$ Treatments, $\mathrm{L}=$ Length, $\mathrm{W}=$ Width, $\mathrm{Tn}=$ Thickness, Arithmetic mean diameter $=\mathrm{Da}$, Geometric mean diameter $=\mathrm{Dg}$, Aspect ratio $=\mathrm{Ra}$ and Cylinderity $=\emptyset$ )

The lowest fruit length was produced by cucumber plants grown under T3 treatment $(135.53 \mathrm{~mm})$ (Fig.1a). The widths of fruits were varied between $34.13 \mathrm{~mm}$ under deficit irrigation T5 and $32.20 \mathrm{~mm}$ for T2 (Fig.1b). The thickness values were ranged from 31.00 $\mathrm{mm}$ (T3) and $33.77 \mathrm{~mm}$ (T1) (Fig.1c). As shown in Fig. (1d), smallest Arithmetic mean diameter was for $\mathrm{T} 3(47.30 \mathrm{~mm})$ and the highest value was for T1 $(55.60 \mathrm{~mm})$. Results of Fig. (1e) showed that T1 had the highest value of Geometric mean diameter (54.73 $\mathrm{mm}$ ), while the lowest value was $51.80 \mathrm{~mm}$ at T3. Regarding aspect ratio, the differences between applied deficit irrigation treatments were not significant (Fig.1f). However, higher aspect ratio of fruits (38.53) was obtained at T6 as compared to other tested deficit irrigation treatments. Lower aspect ratio of cucumber fruits was obtained under T5 treatment (36.90). There on the other hand, there were no significant differences of differences observed due to the applied water treatments on cylinderity of cucumber fruits. The mean values of fruits cylinderity were varied between 0.370 for $\mathrm{T} 5$ and 0.387 for $\mathrm{T} 1$. The above results revealed that the deficit irrigation has no effect on physical characteristics of cucumber crop. These results are in agreement with that obtained by Mao et al. (2003).

\section{Average water utilization efficiency (WUtE):}

The averages of WUtE for cucumber as affected by tested variables are presented in Fig. 2. Average water utilization efficiency (WUtE) values for were 19.76, 27.52, 20.97, $19.71,18.56$ and $18.59 \mathrm{~kg} \mathrm{~m}-3$ for the deficit irrigation treatments, T1, T2, T3, T4, T5, and T6, respectively. Under the effect of $70 \%$ ETC the average of WUtE was increased by $28.21 \%, 23.80 \%, 32.55 \%$, and $32.44 \%$ for $\mathrm{T} 1$, $\mathrm{T} 3, \mathrm{~T} 4, \mathrm{~T} 5$ and $\mathrm{T} 6$ deficit irrigation treatments as compared with $\mathrm{T} 2$, respectively. The average WUtE value under 70\% ETc stresses was higher than the values of other treatments. The average WUtE under T3 treatment was higher than the other treatments. These results are in agreement with Badr et al. (2012) on their study on the effect of deficit irrigation on potato in Egypt and where they showed that plants grown under full irrigation supply resulted in the highest tuber yield and there were significant reductions in total yield and yield components when applying less amount of water. Tuber weight was more sensitive to water deficit than tuber number, where the decrease in potato yield in the deficit water treatments was mainly due to a decrease in tuber weight. Also Mao et al. (2003) in their study on the effect of deficit irrigation on yield and water use of greenhouse grown cucumber in china reported that WUE decreased with increase of irrigation water applied from stem fruiting to the end.

\section{Effect of deficit irrigation treatments on soil chemistry:}


Concentration of soluble salts, expressed as EC value, was higher in the soil treated with $\mathrm{T} 2$ than in the conventionally $\mathrm{T} 1, \mathrm{~T} 3, \mathrm{~T} 4, \mathrm{~T} 5$ and $\mathrm{T} 6$, the differences being significant at the $\mathrm{T} 1, \mathrm{~T} 2, \mathrm{~T} 3, \mathrm{~T} 4, \mathrm{~T} 5$, and $\mathrm{T} 6$ while no significant effect between T3, T4, T5, and T6. Lower value was at T1application rates (Table 5). At $0-2 \mathrm{mS} \mathrm{cm}^{-1}$ salinity effects are mostly negligible and at $2-4 \mathrm{mS} \mathrm{cm}^{-1}$, yields of very sensitive crops may be restricted (Katerji et al., 2005). The cucumber grown in this experiment has medium salt tolerance (Anonymous, 1982) and no salt damage to the crop was observed. The effect of deficit irrigation treatments on chemical properties of soil as recording in table 5 , the $\mathrm{pH}$ of soils received $\mathrm{T} 1(100 \% \mathrm{ETc})$ treatment was less than that of the soil treated with other treatments with significant differences at the T2, T3, T4, T5, T6. The highest value was with the $\mathrm{T} 2(70 \% \mathrm{ETc})$. Difference in the $\mathrm{pH}$ values of deficit irrigation treatment probably contributed to their different effect on soil $\mathrm{pH}$. More applied water can also lower the $\mathrm{pH}$ of soils because of the water reaction and microbial production of $\mathrm{CO}_{2}$ in the soil and around root systems (Pocknee and Sumner, 1997). Deficit irrigation had significant effect on SAR (Table 5).
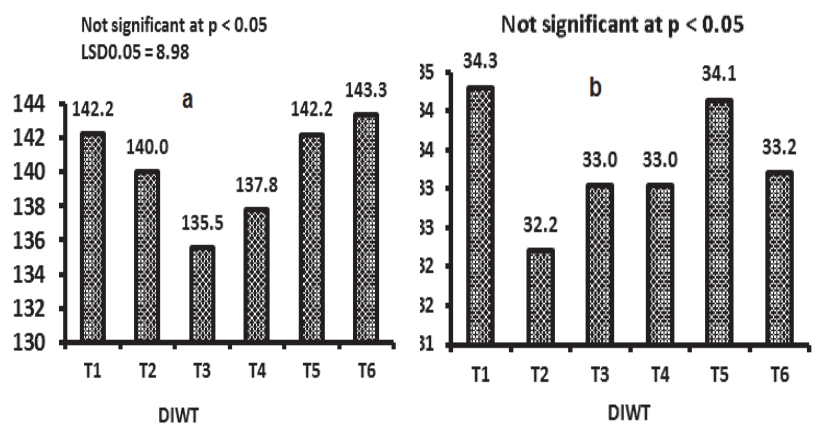
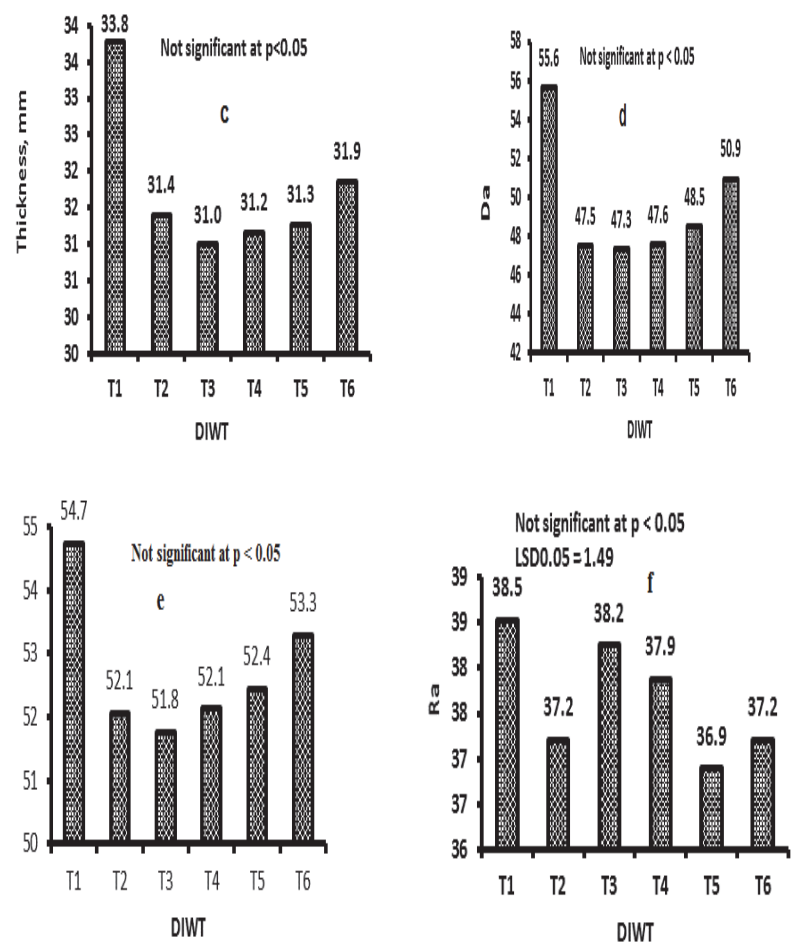

Fig. 1. effect of deficit irrigation water (DI) treatments (T1(100\% ET $\mathrm{E}_{\mathrm{c}}$ at all growth stages), T2(70\% $\mathrm{ET}_{\mathrm{c}}$ at all growth stages), T3 $\left(70 \% \quad\right.$ ET $_{c}$ after full germination until end of season), $\mathbf{T} 4\left(70 \% \mathrm{ET}_{\mathrm{c}}\right.$ at vegetative stage until season end $),$ T5 $\left(70 \% \mathbf{E T}_{\mathrm{c}}\right.$, at flowering stage until season end), and T6 (70\% ET $_{c}$ at first harvest until season end) on fruit length (a), fruit width (b), fruit thickness (c), arithmetic mean diameter, Da (d), geometeric mean diameter, Dg (e), Aspect ratio, Ra (f).

The highly value of SAR was found when the irrigation water was low (T2) and the SAR value reduced with increasing the amount of irrigation water where the SAR ranged between 8.12 (T1 (100\%Etc)) and $11.2(\mathrm{~T} 2$ $(70 \% \mathrm{ETc}))$. 


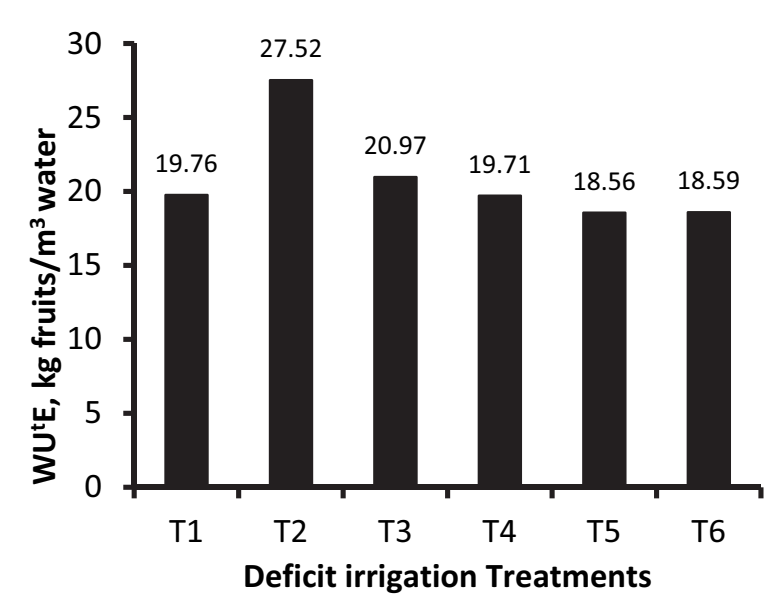

Fig. 2. the relationship between water use efficiency (WUtE) and the deficit irrigation treatments (T1 $\left(100 \%\right.$ ET $_{c}$ at all growth stages), T2 $\left(70 \%\right.$ ET $_{c}$ at all growth stages), $T 3 \quad\left(70 \% \quad \mathbf{E T}_{\mathrm{c}}\right.$ after full germination until end of season), $\mathrm{T} 4\left(\mathbf{7 0} \% \mathrm{ET}_{\mathrm{c}}\right.$ at vegetative stage until season end), $\mathbf{T} 5\left(\mathbf{7 0 \%} \mathrm{ET}_{\mathrm{c}}\right.$, at flowering stage until season end), and T6 (70\%

ET $_{\mathbf{c}}$ at first harvest until season end).

No significant differences between the deficit irrigation treatments on $\mathrm{CaCO} 3 \%$, $\mathrm{OM} \%, \mathrm{P}-\mathrm{NaHCO}_{3}, \mathrm{~K}-\mathrm{HN}_{4}-\mathrm{OAC}, \mathrm{Fe}-\mathrm{DTPA}$, Mn-DTPA, Zn-DTPA and Cu-DTPA of the soil. The higher values of these characters were found when the soil treated with T2 $(70 \% \mathrm{ETc})$ treatment. On the opposite of that, the lower values were found in soils that received the highest amount of water and especially treatment T1 $(100 \% \mathrm{ETc})$. This means that the deficit irrigation does not affect nor helps the leaching of essential nutrient elements from surface layer of the soil.

\section{Conclusions}

Results clearly revealed that, the applied deficit irrigation at different periods of growth lead to decline the qualities of yield and yield components of cucumber of the compared to irrigation at $100 \% \mathrm{ETc}$. The regularity of fixed irrigation quantities during the crop

Table 5. Effect of treatments with deficit irrigation (T1(100\% ET $\mathrm{E}_{\mathrm{c}}$ at all growth stages), $\mathrm{T}_{2}\left(\mathbf{7 0} \% \mathrm{ET}_{\mathrm{c}}\right.$ at all growth stages), T3 $\left(\mathbf{7 0 \%}\right.$ ET $_{\mathrm{c}}$ after full germination until end of season), $\mathbf{T} 4\left(\mathbf{7 0 \%} \mathbf{E T}_{\mathrm{c}}\right.$ at vegetative stage until season end $),$ T5 $\left(70 \% \mathbf{E T}_{\mathrm{c}}\right.$, at flowering stage until season end), and T6 (70\%
ET $_{c}$ at first harvest until season end) on EC, pH and elemental composition (in ppm) of the soil at the end cucumber harvest.

\begin{tabular}{|c|c|c|c|c|c|c|c|c|}
\hline \multirow{2}{*}{$\begin{array}{c}\text { Characte } \\
\text { rs }\end{array}$} & \multicolumn{6}{|c|}{ Treatments } & \multirow{2}{*}{$\begin{array}{c}\text { LSD } \\
0.05\end{array}$} & \multirow{2}{*}{$\begin{array}{l}\text { CV } \\
\%\end{array}$} \\
\hline & T1 & $\mathbf{T} 2$ & T3 & T4 & T5 & T6 & & \\
\hline $\begin{array}{c}\mathrm{EC}, \mathrm{mS} \\
\mathrm{cm}^{-1}\end{array}$ & $\begin{array}{c}1.75 \\
\mathrm{c}\end{array}$ & $\begin{array}{c}2.38 \\
\mathrm{a}\end{array}$ & $\underset{b}{2.18}$ & $\begin{array}{c}2.17 \\
\mathrm{~b}\end{array}$ & $\begin{array}{c}2.15 \\
\mathrm{~b}\end{array}$ & $2.18^{b}$ & $\begin{array}{c}0.63 \\
0 \\
\end{array}$ & $\begin{array}{c}5.3 \\
0 \\
\end{array}$ \\
\hline $\mathrm{pH}$ & $\begin{array}{c}7.23 \\
\text { NS }\end{array}$ & $\begin{array}{c}7.84 \\
\text { NS }\end{array}$ & $\begin{array}{c}7.45 \\
\text { NS }\end{array}$ & $\begin{array}{l}7.47 \\
\text { NS }\end{array}$ & $\begin{array}{l}7.35 \\
\mathrm{NS}\end{array}$ & $\begin{array}{c}7.37^{\mathrm{N}} \\
\mathrm{s}\end{array}$ & 1.34 & $\begin{array}{l}10 . \\
02\end{array}$ \\
\hline SAR & $\underset{b}{8.12}$ & $\begin{array}{c}11.2 \\
\mathrm{a}\end{array}$ & $\begin{array}{c}10.9 \\
4^{\mathrm{a}}\end{array}$ & $\begin{array}{c}10.3 \\
4^{\mathrm{ab}}\end{array}$ & $\begin{array}{c}10.7 \\
7^{\mathrm{a}}\end{array}$ & $\begin{array}{c}10.08 \\
\text { ab }\end{array}$ & 2.06 & $\begin{array}{l}11 . \\
03\end{array}$ \\
\hline $\mathrm{CaCO}_{3} \%$ & $\begin{array}{c}5.22 \\
\text { NS }\end{array}$ & $\begin{array}{c}5.00 \\
\text { NS }\end{array}$ & $\begin{array}{c}5.25 \\
\text { NS }\end{array}$ & $\begin{array}{l}4.89 \\
\text { NS }\end{array}$ & $\begin{array}{c}4.75 \\
\text { NS }\end{array}$ & $\begin{array}{c}4.99^{\mathrm{N}} \\
\mathrm{s}\end{array}$ & 1.42 & $\begin{array}{c}15 . \\
9\end{array}$ \\
\hline OM\% $\%$ & $\begin{array}{l}0.00 \\
75^{\mathrm{NS}}\end{array}$ & $\begin{array}{l}0.00 \\
90^{\mathrm{NS}}\end{array}$ & $\begin{array}{l}0.00 \\
75^{\mathrm{NS}}\end{array}$ & $\begin{array}{l}0.00 \\
82^{\mathrm{NS}}\end{array}$ & $\begin{array}{l}0.00 \\
80^{\mathrm{NS}}\end{array}$ & $\begin{array}{c}0.007 \\
5^{\mathrm{NS}}\end{array}$ & $\begin{array}{c}0.00 \\
2\end{array}$ & $\begin{array}{l}14 . \\
85\end{array}$ \\
\hline Total N\% & $\begin{array}{c}0.04 \\
7^{\mathrm{NS}}\end{array}$ & $\begin{array}{c}0.05 \\
6^{\mathrm{NS}}\end{array}$ & $\begin{array}{c}0.04 \\
7^{\mathrm{NS}}\end{array}$ & $\begin{array}{l}0.05 \\
1^{\mathrm{NS}} \\
\end{array}$ & $\begin{array}{c}0.05 \\
0^{\mathrm{NS}}\end{array}$ & $\begin{array}{c}0.047 \\
\text { NS }\end{array}$ & $\begin{array}{c}0.01 \\
3\end{array}$ & $\begin{array}{l}15 . \\
05\end{array}$ \\
\hline $\begin{array}{c}\mathrm{P}- \\
\mathrm{NaHCO}_{3}, \\
\mathrm{ppm}\end{array}$ & $\begin{array}{c}3.84 \\
\text { NS }\end{array}$ & $\begin{array}{c}4.53 \\
\text { NS }\end{array}$ & $\begin{array}{c}4.02 \\
\text { NS }\end{array}$ & $\begin{array}{l}4.12 \\
\text { NS }\end{array}$ & $\begin{array}{l}4.05 \\
\text { NS }\end{array}$ & $\begin{array}{c}4.17^{\mathrm{N}} \\
\mathrm{s}\end{array}$ & 1.04 & $\begin{array}{l}13 . \\
85\end{array}$ \\
\hline $\begin{array}{c}\mathrm{K}-\mathrm{HN}_{4-} \\
\mathrm{OAC} \\
\mathrm{ppm}\end{array}$ & $\begin{array}{c}195^{\mathrm{N}} \\
\mathrm{S}\end{array}$ & $\begin{array}{c}250^{\mathrm{N}} \\
\mathrm{s}\end{array}$ & $\begin{array}{l}204 \\
1^{\mathrm{NS}}\end{array}$ & $\underset{\mathrm{s}}{210^{\mathrm{N}}}$ & $\begin{array}{c}230^{\mathrm{N}} \\
\mathrm{s}\end{array}$ & $220^{\mathrm{NS}}$ & $\begin{array}{c}79.4 \\
6\end{array}$ & $\begin{array}{l}20 . \\
02\end{array}$ \\
\hline $\begin{array}{c}\text { Fe-DTPA, } \\
\text { ppm }\end{array}$ & $\begin{array}{c}18.7 \\
\text { NS }\end{array}$ & $\begin{array}{c}19.2 \\
\text { NS }\end{array}$ & $\begin{array}{c}19.0 \\
\text { NS }\end{array}$ & $\begin{array}{c}18.9 \\
\mathrm{NS}\end{array}$ & $\begin{array}{c}18.8 \\
\mathrm{NS}\end{array}$ & $\begin{array}{c}18.83 \\
\text { NS }\end{array}$ & 5.85 & $\begin{array}{l}17 . \\
02\end{array}$ \\
\hline $\begin{array}{c}\text { Mn- } \\
\text { DTPA, } \\
\text { ppm }\end{array}$ & $\begin{array}{c}6.2^{\mathrm{N}} \\
\mathrm{s}\end{array}$ & $\begin{array}{c}7.01 \\
\text { NS }\end{array}$ & $\begin{array}{c}6.0^{\mathrm{N}} \\
\mathrm{s}\end{array}$ & $\begin{array}{l}6.1^{\mathrm{N}} \\
\mathrm{s}\end{array}$ & $\begin{array}{c}6.4^{\mathrm{N}} \\
\mathrm{s}\end{array}$ & $6.5^{\mathrm{NS}}$ & 2.19 & $\begin{array}{l}18 . \\
88\end{array}$ \\
\hline $\begin{array}{c}\mathrm{Zn-} \\
\text { DTPA, } \\
\text { ppm }\end{array}$ & $\begin{array}{c}2.90 \\
\text { NS }\end{array}$ & $\underset{\text { NS }}{3.25}$ & $\begin{array}{c}3.00 \\
\text { NS }\end{array}$ & $\begin{array}{c}3.08 \\
\text { NS }\end{array}$ & $\begin{array}{c}3.18 \\
\mathrm{NS}\end{array}$ & $\underset{\mathrm{S}}{3.14^{\mathrm{N}}}$ & 0.96 & $\begin{array}{l}17 . \\
05\end{array}$ \\
\hline $\begin{array}{c}\text { Cu- } \\
\text { DTPA, } \\
\text { ppm }\end{array}$ & $\begin{array}{c}1.0^{\mathrm{N}} \\
\mathrm{s}\end{array}$ & $\begin{array}{c}1.6^{\mathrm{N}} \\
\mathrm{s}\end{array}$ & $\underset{\mathrm{s}}{1.2^{\mathrm{N}}}$ & $\begin{array}{c}1.3^{\mathrm{N}} \\
\mathrm{s}\end{array}$ & $\begin{array}{c}1.4^{\mathrm{N}} \\
\mathrm{S}\end{array}$ & $1.1^{\mathrm{NS}}$ & 0.43 & $\begin{array}{l}19 . \\
25\end{array}$ \\
\hline
\end{tabular}

Means in each row for each parameter followed by the same letter are not significantly different according to least significant differences at 0.05 level of significant $\left(\mathrm{LSD}_{0.05}\right)$.

growth led to higher values for yield and yield component. Physical properties of cucumber fruits was not influenced by deficit irrigation. The highest water use efficiency was found in $70 \% \mathrm{ETc}$. Soil $\mathrm{pH}, \mathrm{EC}$ and SAR significantly decreased with increasing irrigation water level. That meaning the quantity of irrigation water may improves the properties of soil but decrease the available nutrients of $\mathrm{P}, \mathrm{K}, \mathrm{N}, \mathrm{Fe}, \mathrm{Mn}, \mathrm{Zn}$, and $\mathrm{Cu}$. In conclusion, deficit irrigation $70 \%$ ETc can be used to grow cucumber in the area under study.

\section{Acknowledgements}

This paper was extracted from research project, which funded by the Deanship of Scientific Research of King Faisal University, 
Saudi under grant No. 130114. The authors and researchers team therefore acknowledge with thanks to Deanship of Scientific Research of King Faisal University.

\section{References}

Albaloushi, N. S. (2012) Physical characteristics of tomato fruits. Minufiya J. Agric Res. 37(2): 313-323.

Alomran, A. M., Louki, I. I., Aly, A. A., Nadeem, M. E. (2013) Impact of deficit irrigation on soil salinity and cucumber yield under greenhouse condition in an arid Environment. J. Agr. Sci. Tech. Vol. 15: 1247-1259

Amer, K. H., Midan, S. A. and Hatfield, J. L. (2011) Effect of deficit irrigation and fertilization on Cucumber. Agron. J. 101:1556-1564.

Anonymous. (1982) Salinity problems of the dry land region http://www.fao.org/ docrep/x5871e/x5871e06.htm\#TopOfPage regions.http://www.fao.org/.

Arzani K., Arzani D., Wood G.S. (2000) Influence of first season application of paclobutrazol, root-pruning and regulated deficit irrigation on second season flowering and fruiting of mature "Sundrop" apricot trees. Acta Hort., 5(16): $75-82$.

Badr, M. A., El-Tohamy, W. A., and Zaghloul, A. M. (2012) Yield and water use efficiency of potato grown under different irrigation and nitrogen levels in an arid region. Agricultural Water Management 110, 9-15.

Chartzoulakis, K., Drosos, N. (1997) Water requirements of glasshouse grown pepper under drip irrigation. Acta Hort. 499, 175-180.

Cifre, J., Bota, J., Escalona, J. M., Medrano, H. and Flexas, J. (2005) Physiological tools for classification methods. Agric. Water Manage., 62: 37-66.

El-Waraky, Y.B.A. (1988) Effect of nitrogen fertilizer and plant population on growth, yield and quality of cucumber (Cucumes sativas, L). M. Sci. Thesis, Fac. Agric., Alex. Univ., Egypt.

English, M. J., Raja, S. N. (1996) Perspective of deficit irrigation. Agric. Water Manage., Exp. Bot., 58 (2): 147159.

FAO (1979) Yield response to water by Doorenbos, J. and Kasssam, A. FAO Irrigation and drainage papaers No.33, Rome, Italy.

FAO Report (2002) Deficit Irrigation Practices. FAO, Rome, $102 \mathrm{p}$.

Fereres, E. and Evans R. G. (2006) Irrigation of fruit trees and vines: an introduction. Irrigation Science 24, 55-57.

Grant, O. M., Stoll, M. and Jones, H. G. (2004) Partial rootzone drying does not affect fruit yield of raspberries. Journal of Horticultural Science and Biotechnology 79, $125-130$.

http://msucares.com/lawn/garden/vegetables/list/cucumber .html. (2014) Web page information: webmaster@ext.msstate.edu. This page was last updated on August 21, 2014.
Hutton, R. (2000) improving the water use efficiency Internationale, Besoins en Eau des Cultures. Hutton, Farmers' newsletter, pp. 497-514.

Jensen, M. E. (1983) Design and operation of farm irrigation systems. Amer. Soc. Agric. Eng. Michigan, USA, p.827.

Katerji, N., van Hoorn, J.W., Hamdy A. and Mastrorilli, M. (2005) Salinity effect on crop development and yield, analysis of salt tolerance according to several classification methods. Méditerranéennes Série A, 66: $125-146$

Kirda, C. (2000) Deficit irrigation scheduling based on plant growth stages showing water stress tolerance.In Deficit irrigation practices. Nielsen (eds).WaterReport No22 FAO, Rome.

Kirda, C., Cetin, M., Dasgan, Y., Topcu, S., Kaman, H., Ekici, B., Derici, M.R. and Ozguven, A.I. (2004) Yield response of greenhouse grown tomato to partial root drying and conventional deficit irrigation. Agric. Water Manage. 69, 191-201.

Kramer, P. J. (1969) Plant and water relationships. A modern synthesis. McGraw-Hill, New York.

Mao, X., Liu, M., Wang, X., Hou, C. Z. and Shi, J. (2003) Effects of deficit irrigation on yield and water Use of greenhouse grown cucumber in the North China Plain. Agric. Water Manag., 61(3): 219228.

Mirzaei, H., McBee, J. K., Watts, J. and Aebersold R.. (2008) Comparative evaluation of current peptide production platforms used in absolute quantification in proteomics. Mol Cell Proteomics 7: 813-823.

Mohsenin, N. N. (1970) Physical Properties of Plant and Animal Material, Vol. 1, New York Press, Gordon and Breech.

Mohsenin, N. N. (1986) Physical properties of plant and animal materials, Gordon and Breach Sc. Pub., N. Y.

Nahar, K. and Ralph, G. (2002) "Effect of water stress on nutrient uptake, yield and quality of tomato (L.e) under subtropical conditions". Austrian Journal of Agricultural Research (Vienna, Austria: Die Bodenkultur) 53 (1): 4551.

Nesvadba, N., Oka, T., Hasegawa, T., Hayashi, M. and Handa, T. (2007) Intense star formation and feedback at high redshift: spatially-resolved properties of the $\mathrm{z}=2.6$ submillimeter galaxy SMMJ14011+0252ApJ, 657, 725 .

Page, A. L., Miller, R.H., and Keeny, R. D. (1982) Methods of soil analysis: Part II. Chemical and Biochemical Properties ( $2^{\text {nd }}$ edition). Monograph No. 9, ASSS, Madison, WI, USA.

Pocknee, S. and Sumner, M. E. (1997) Cation and nitrogen contents of organic matter determine its soil liming potential. Soil Sci. Soc. Am. J., 61, 86-92

Razavi, S. M. and Parvar, M. B. (2007) Some physical and mechanical properties of kiwifruit, International J. Food Eng., 3 (6): 1-14.

Russell, W. (1973) Soil Conditions and Plant Growth. 10 $0^{\text {th }}$ Edition. Printed in Great Britain by William Clowes \& Sons, Limited. London, Beccles and Colchester. 
SAS institute (2001) SAS for windows, SAS user'guide: Statistics. Version 8.0e. SAS Inst., Inc., Cary, North Carolina.

Steel, R. G. D. and Torries, J. H. (1980) Principle and Procedure of Statistic a Biomaterial Approach. 2nd Edn. McGrow-Hill. New York, USA. ISBN: 0-07060-926-8.

Strefeler, M. S. and Wehner, T. C. (1986) Estimates of heritabilities and genetic variances of three yield and five quality trails in three fresh market cucumber populations. J. Amer. Soc. Hort. Sci., 111: 599-605.

Van Schilfgaarde, J. (1994) Irrigation- a Blessing or a Curse. Agricultural Water Management 25: 203-219.

Vermeiren, R. and Gopling, L. (1984) Model for Hysteresis and Kink Behavior of MOS Transistors Operating at 4.2 K. IEEE transactions on electron devices, 31 (2).

Wakrim, R., Wahbi, S., Tahi, H., Aganchich, B. and Serraj, R., (2005) Comparative effects of partial root drying (PRD) and regulated deficit irrigation

Xuesen, M., Mengyu, L., Xinyuan, W., Changming, L., Zhimin, H. and Jnzhi, S. (2003) Effects of deficit irrigation on yield and water use of greenhouse grown cucumber in the North China Plain. Agricultural Water Management, V. 61 (3): 219-228.

Yehia, I., Kabeel, M. H. and Abdel Galeel, M. M. (2009) Physical and mechanical properties of Ponkan mandarin applied to grading machine, Misr J. Ag. Eng., 26 (2): 1036-1053. 


\section{تأثثر الري الناقص على صفات التزبة الكيميائية، و المحصول ومكوناته، وصلابة ثمار الخيار (Cucumis sativus L.) تحت ظروف المنطقة الجافة، الأحساء، المملكة العربية

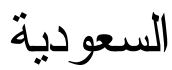

\section{محمد محمد الجروانى ونبيل سعود البلوشى"}

محطة التنربب والأبحاث الزراعبة والبيطرية و* قسم هندسة النظم الزر/عية بكلية العلوم الزرراعبة

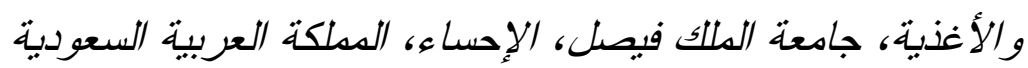

المستخص: أجريت هذه التجربة بالبيوت المحمية في محطة التدريب و الأبحاث الزر اعية و البيطرية

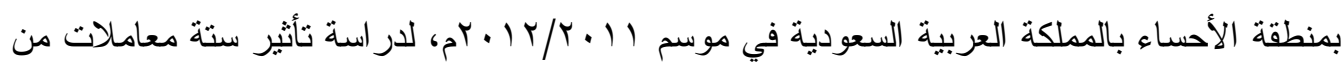

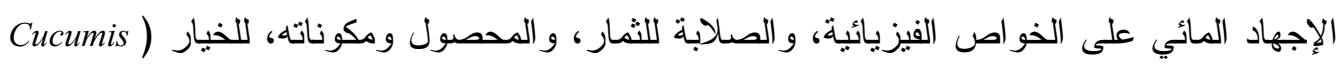
(sativus L.

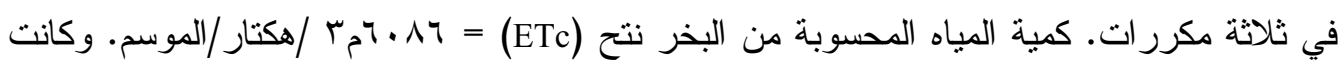

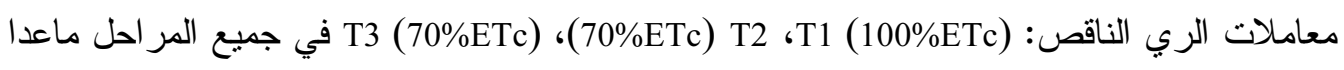

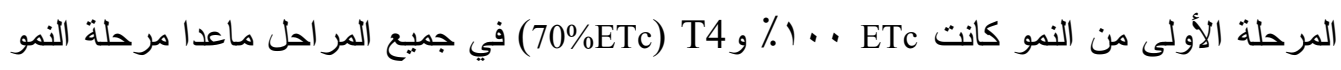

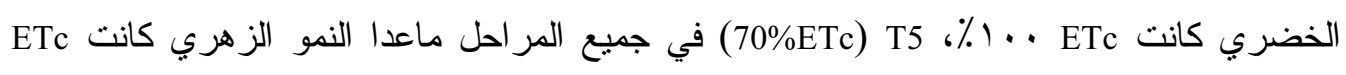

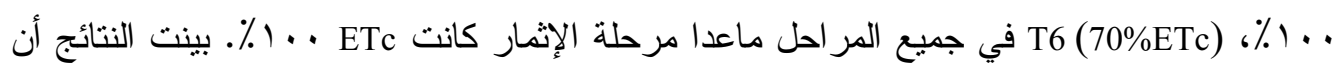

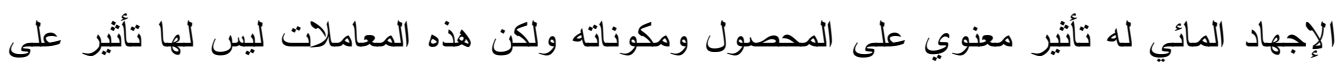

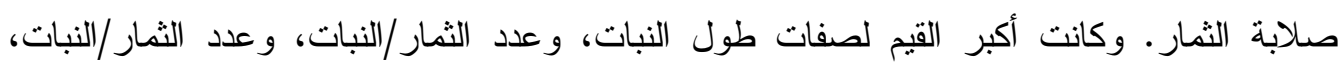

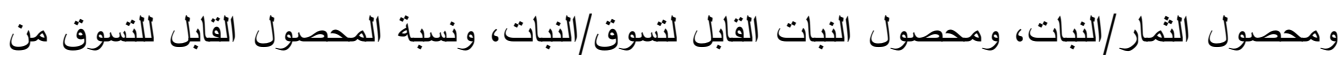

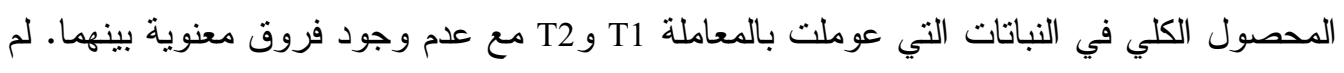

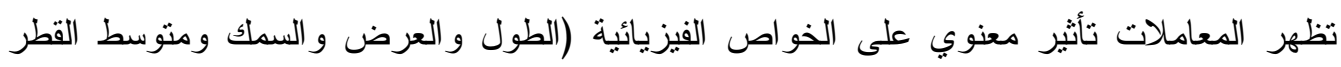

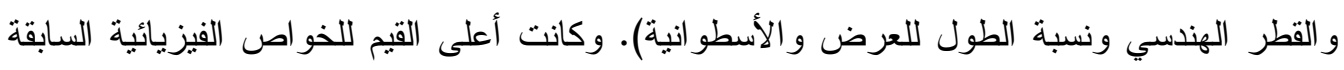

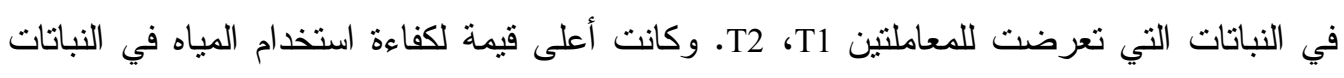

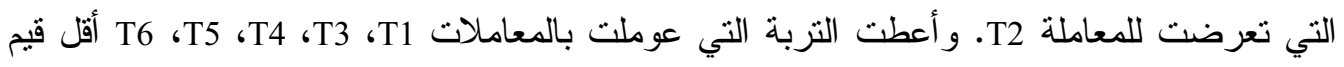

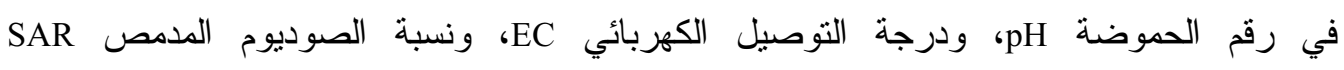

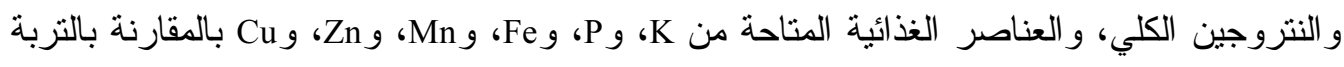
التي عوملت بالمعاملة T2. لا يوجد فروق معنوية بين المعاملات في ثأثيرها على النسبة المئوية ولنية 
لكربونات الكالسيوم، و النسبة المئوية للنيتزوجين الكلي، و العناصر الغذائية المتاحة للنبات K، وP، و و الكلمات الافتتاحية: الإجهاد المائي، و الخيار، ومكونات المحصول، و الخو اص الفيزيائية، و الصلابة. 